\title{
Evaluation of the Effect of Using 2,3-dichlorovinyl Dimethyl Phosphate (sniper) as Storage Insecticide on Quality of Cowpea (Vigna unguiculata (L.) Walp) Nutritional Content
}

\author{
T. D. Tizhe, J. K. Dagze, C. S. Yusuf, J. Jacob, and S. M. Mallum
}

\section{ABSTRACT}

The effect of 2, 3-dichlorovinyl dimethyl phosphate (sniper) application on the nutritional contents of cowpea over a period of time has been investigated. The chemical free cowpea samples were purchased directly from local farmers in Mubi town, Adamawa State. Three different treatment rates of 5,10 and $15 \mathrm{ml}$ of sniper were used. Each of the treatment rates was applied to $13 \mathrm{~kg}$ of cowpea and was placed in an air tight galloon. Another galloon containing $13 \mathrm{~kg}$ of cowpea without chemical treatment was used as the control sample. These were kept for a period of 30 and 60 days before analysis. The proximate and mineral components of the cowpea were analyzed using standard procedures. Assessment of the proximate composition revealed varied concentrations of protein, carbohydrate, ash, fat, crude fibre and moisture that ranges between $22.79-26.16 \%, 58.85$ $60.86 \%, 3.85-5.88 \%, 2.25-2.53 \%, 1.52-1.76 \%$ and $5.90-6.85 \%$, respectively. Most of the proximate compositions were observed to decrease with increase in sniper concentration and storage duration. The proximate contents at 60 days after treatment application were observed to be significantly lower than that at 30 days. The mineral components analyzed ranges between 185.03-195.54 $\mathrm{mg} / 100 \mathrm{~g}(\mathrm{P}), 226.32-245.76 \mathrm{mg} / 100 \mathrm{~g}(\mathrm{Ca})$, 80.76-85.92 $\mathrm{mg} / 100 \mathrm{~g}(\mathrm{Mg})$ and $595.25-642.34 \mathrm{mg} / 100 \mathrm{~g}(\mathrm{~K})$ respectively; and at day 60 it ranges between $186.54-198.65 \mathrm{mg} / 100 \mathrm{~g}, 251.07$ $262.73 \mathrm{mg} / 100 \mathrm{~g}, \mathbf{8 6 . 4 8 - 9 0 . 1 2} \mathrm{mg} / 100 \mathrm{~g}$ and $650.06-700.04 \mathrm{mg} / 100 \mathrm{~g}$ respectively. The mineral contents were observed to increase with increase in treatment concentrations as well as storage duration. Therefore, sniper has significant effect on the proximate and mineral contents of cowpea. The effect depends on the rate and duration of storage. The use of sniper as an insecticide in the storage of cowpea should therefore be discouraged.

Keywords: Cowpea, duration of storage, mineral nutrients, proximate composition, sniper.

\section{INTRODUCTION}

Cowpea (Vigna unguiculata (L) Walp), also known as southern pea, black-eye pea, crowder pea, asparagus bean, is an annual herbaceous legume from the family of Fabaceae, grown mostly in the continent of Africa, especially in Nigeria and Niger, accounting for about $70 \%$ of the world production [1]. In West and Central Africa, the areas on which cowpea is cultivated and its production have both increased in the last decade with production 3 million tons annually on the species known as $V$. unguiculata, but categorized into four distinct cultivars, namely: Unguiculata, Biflora, Sesquipedalis and Textilis. They are differentiated from one another based on some physiological and morphological factors such as: seed size and color, taste, yield, and period to maturity [4]. It is grown mainly as a source of food to humans average [2], [3]. All cowpea cultivated are grouped under one
Published Online: July 29, 2021

ISSN: 2684-5199

DOI: 10.24018 /ejbio.2021.2.4.230

\section{T. D. Tizhe*}

Department of Botany, Adamawa State University, Mubi, Nigeria.

(e-mail: taritizhe@yahoo.com)

J. K. Dagze

Department of Science Laboratory Technology, The Federal Polytechnic, Mubi, Nigeria.

(e-mail: kagana2015@gmail.com)

C. S. Yusuf

Department of Botany, Adamawa State University, Mubi, Nigeria.

(e-mail: baldeino67@gmail.com)

J. Jacob

Department of Chemistry, Air Force Institute of Technology, Nigerian Air Force Base, Kaduna, Nigeria.

(e-mail: jacobyumar@gmail.com)

S. M. Mallum

Department of Botany, Adamawa State University, Mubi, Nigeria.

(e-mail: mallummidawa@ ${ }^{\text {gmail.com) }}$

*Corresponding Author and feed to livestock [5]; and also serve as a major source of income to small holder farmers, especially in West and Central Africa. It is estimated that around $80 \%$ of cowpea trade in the world is in the region of West and Central Africa [2], [3], [6]. Recently, cowpea has gained much attention like never before from its consumers and researchers all over the world because of its health benefits some of which include anti-diabetic, anti-cancer, anti-hyperlipidemic, antihypertensive and anti-inflammatory [7]. It is also a very rich source of proteins, calories as well as vitamins and minerals [8]. Different researchers reported the presence of proximate compositions such as: ash, moisture, carbohydrate, protein, crude fat and fibre; and minerals like sodium, potassium, calcium, phosphorus, magnesium, iron and zinc at varied concentrations in cowpea [9], [10].

The storage of cowpea grains has always been a great challenge to scale farmers owing to its susceptibility to 
insects' attack. This has often necessitated the sale of this product at a very low price and at unintended period so as to avoid loss during storage [11]. Cowpea storage loss attributed to insects' attack was estimated to be at $25 \%$ [12], [13] and as high as $95 \%$ depending upon the location, year, and seed cultivar [14]. The most important among these insects that attack cowpea especially at postharvest is weevil (Callosobruchus maculatus), which was reported to be responsible for up to $60 \%$ losses or higher during storage [15], [16].

In an effort to control these post-harvest cowpea pests, farmers use varieties of both commercial and traditional methods; many of which are very expensive and toxic. The use of chemicals as repelling agent of insects attack in cowpea has become common practice among farmers in Nigeria. For example, some insecticides are used to control weevils in cowpeas and other pre-harvest pests. However, some these chemicals are not easy to come by for most peasant farmers. For those that could, the issue of misuse may result in health and environmental concerns [11]. Some of these low income farmers resort to the use of some cheap, but dangerous synthetic insecticides like 2, 3-dichorovinyl dimethyl phosphate (sniper) in control of post-harvest pests. The effect of these storage chemicals and their effects on the nutritional contents of cowpea are generating a lot of concerns among the populace in recent times. The need to assess the effect of sniper as a common storage chemical of cowpea on its nutritional quality over specified period of storage becomes expedient.

\section{MATERIALS AND MethodS}

\section{A. Sample Collection}

The cowpea ("Banjaram" variety) samples were obtained from directly from local farmers at Kasuwan Buhu in Mubi main market. It was ensured that there was no added chemical prior to purchase.

\section{B. Chemical Treatment of Cowpea}

The insecticide used (2, 3-dichlorovinyl dimethyl phosphate) known by a trade name "sniper" was applied at three different rates. These include: $5 \mathrm{ml}, 10 \mathrm{ml}$, and $15 \mathrm{ml}$. Each of these treatments rates was applied to $13 \mathrm{~kg}$ of cowpea using a syringe, mixed thoroughly and was put into air tight galloons. The same quantity $(13 \mathrm{~kg})$ of the cowpea without chemical treatment was used as the control sample. These samples (treated and untreated) were kept over a period of 30 and 60 days respectively before analysis.

\section{Sample Preparation}

About $2 \mathrm{~g}$ of powdered cowpea seed samples were mixed with $25 \mathrm{ml}$ of acetonitrite and methanol. The mixtures were shaken vigorously and then allowed to stand for one hour. The supernatants were filtered using Whatmann number 4 filter paper. The extracts were transferred into a sterile bottle for chromatography analysis.

\section{Analysis of Proximate Compositions}

Proximate compositions which include moisture content, crude fibre, crude fat, protein, carbohydrate, and ash content were all determined using the methods described by [17].

\section{E. Minerals Content Analysis}

Samples were digested using concentrated nitric acid and sulfuric acid (3:1, v/v). The minerals ( $\mathrm{P}, \mathrm{K}, \mathrm{Ca}$, and $\mathrm{Mg}$ ) were estimated using an atomic absorption spectrophotometer (210, Buck Scientific USA).

\section{RESUlTS}

A. Proximate Compositions of Cowpea at 30 and 60 Days after Application of 2, 3-Dichlorovinyl Dimethyl Phosphate (Sniper)

The cowpea proximate analysis at 30 days after treatment application (Table I) revealed a decrease in the cowpea's content of the crude protein, fat and crude fibre with increase in the treatment concentration. These contents were significantly different from each other with the control contents being the highest and that of the $15 \mathrm{ml}$ treatment the lowest. Almost similar results for the moisture content was observed as the control moisture content (6.85\%) was significantly the highest while those of all the treatments (5$15 \mathrm{ml}$ ) were the lowest with $6.00 \%$ each. However, this is in contrast with the results of ash and carbohydrate contents as they seem to increase significantly with increase in treatments concentration, with the control contents $(3.85$ and $58.85 \%$, respectively) being the lowest.

After 60 days of chemical treatment, the moisture content results were not significantly different that of the control sample (with $5.95 \%$ ). The protein content was observed to decrease with increase in the treatment concentration; as the control sample $(24.12 \%)$ had the highest content but was not significantly different from that of $5 \mathrm{ml}(24.10 \%)$ whereas that of the $15 \mathrm{ml}$ treatment was the lowest with $22.79 \%$. The fat and crude fibre contents of the lowest treatment concentration $(5 \mathrm{ml})$ were significantly the highest with 2.41 and $1.65 \%$, respectively as against that of the control $(2.25$ and $1.5 \%$ ), which were the lowest significantly. The ash content on the other hand was observed to decrease with increase in treatment concentrations; with $15 \mathrm{ml}$ treatment concentration being the highest with $6.20 \%$ while that of the control the lowest with $5.72 \%$. In terms of the carbohydrate content, $10 \mathrm{ml}$ treatment had the highest content with 61.02 $\%$ followed by that of the control $(60.47 \%)$ while the least was that of $5 \mathrm{ml}$ with $60.09 \%$ (Table I).

B. Comparison of the Effect of Storage Duration On Proximate Compositions of Cowpea Applied Sniper At Different Concentrations

Comparison of the effect of storage duration on cowpea proximate compositions, after sniper application indicated that the crude protein content of the of the cowpea at 30 days of storage after application of the different concentrations [5 $\mathrm{ml}(25.95 \%), 10 \mathrm{ml}(25.13 \%)$ and $15 \mathrm{ml}(24.15 \%)]$ and even the control sample $(26.16 \%)$ were significantly the highest, whereas that at 60 days of storage $[5 \mathrm{ml}(24.10 \%), 10 \mathrm{ml}$ $(23.96 \%)$ and $15 \mathrm{ml}(22.79 \%)]$, the lowest at all concentrations. The fat content of the cowpea at 30 and 60 days of storage after treatments application were not statistically significantly different at $p<0.05$. However, the fat content of the control cowpea at 30 days after storage was significantly the highest and lowest at 60 days. The crude fibre content of the cowpea applied concentrations $10 \mathrm{ml}$ 
$(1.62 \%)$ and $15 \mathrm{ml}(1.59 \%)$ and the control sample $(1.76 \%)$ were significantly the highest at 30 days duration of storage and lowest at 60 days. However, the content at 30 days $(1.70 \%)$ and at $60(1.65 \%)$ after application of $5 \mathrm{ml}$ of the treatment were not significantly different (at $\mathrm{p}<0.05$ ). Contrary observation was made in the case of the ash content at 30 days after application of concentrations $5-15 \mathrm{ml}$ as the content (4.00, 4.00 and $5.12 \%$, respectively) were significant the lowest, but highest at 60 days after storage at the same concentrations with $5.85,5.88$ and $5.20 \%$, respectively. The control sample on the other hand had $3.85 \%$ as the ash content after 30 days of storage, which is significantly higher than that of 60 days $(5.72 \%)$. The cowpea moisture content was observed to be significantly higher at all concentrations as well as the control at 30 days after storage, but lower at day 60 . The carbohydrate of the cowpea was at 60 days duration of storage after application of $5 \mathrm{ml}$ concentration significantly higher than that at 30 days. Similar result was obtained for the control sample. The carbohydrate content at all durations of storage after application of $10 \mathrm{ml}$ concentration was not statistically significantly different. However, at day 30 after
$15 \mathrm{ml}$ concentration application, the carbohydrate content $(60.81 \%)$ was significantly the highest and lowest at day 60 with $60.22 \%$ (Table II).

\section{B. Mineral Compositions of Cowpea at 30 and 60 Days after Application of 2, 3-dichlorovinyl Dimethyl Phosphate (Sniper)}

The P (195.54 mg/100 g), Ca (245.76 mg/100 g), Mg $(85.92 \mathrm{mg} / 100 \mathrm{~g})$ and $\mathrm{K}(642.34 \mathrm{mg} / 100 \mathrm{~g})$ of cowpea applied $15 \mathrm{ml}$ of sniper analyzed after 30 days were significantly the highest followed by those of $10 \mathrm{ml}[\mathrm{P}$ (193.33 mg/100g), Ca (240.15 mg/100 g, Mg (82.64 mg / $100 \mathrm{~g}$ and $\mathrm{K}(615.64 \mathrm{mg} / 100 \mathrm{~g})]$. The $\mathrm{P}(178.54 \mathrm{mg} / 100 \mathrm{~g})$, $\mathrm{Ca}(211.26 \mathrm{mg} / 100 \mathrm{~g}), \mathrm{Mg}(75.86 \mathrm{mg} / 100 \mathrm{~g})$ and $\mathrm{K}$ $(545.26 \mathrm{mg} / 100 \mathrm{~g})$ of the control cowpea were significantly the lowest. Similar results were observed at 60 days after the application of 5, 10 and $15 \mathrm{ml}$ of the sniper and even the control sample as the significantly highest and lowest contents of $\mathrm{P}, \mathrm{Ca}, \mathrm{Mg}$ and $\mathrm{K}$ were recorded at the $15 \mathrm{ml}$ and control cowpea samples respectively (Table III).

TABLE I: ProXimate Compositions of COWPEA AT DifFERENT DURATION OF STORAGE AFTER APPLICATION OF SNIPER CHEMICAL

\begin{tabular}{cccccccc}
\hline \multirow{2}{*}{ Treatment } & \multirow{2}{*}{ Dos } & \multicolumn{5}{c}{ Proximate composition (\%) } \\
\cline { 3 - 7 } & & C. Protein & Fat & C. Fibre & Ash & Moist. & Carb. \\
\hline \multirow{2}{*}{$5 \mathrm{ml}$} & \multirow{2}{*}{30 Days } & $25.95 \pm 0.00^{\mathrm{b}}$ & $2.45 \pm 0.00^{\mathrm{b}}$ & $1.70 \pm 0.00^{\mathrm{b}}$ & $4.00 \pm 0.00^{\mathrm{b}}$ & $6.00 \pm 0.00^{\mathrm{b}}$ & $59.90 \pm 0.00^{\mathrm{c}}$ \\
$10 \mathrm{ml}$ & & $24.13 \pm 0.01^{\mathrm{c}}$ & $2.40 \pm 0.00^{\mathrm{c}}$ & $1.62 \pm 0.00^{\mathrm{c}}$ & $4.00 \pm 0.00^{\mathrm{b}}$ & $6.00 \pm 0.00^{\mathrm{b}}$ & $60.86 \pm 0.01^{\mathrm{a}}$ \\
$15 \mathrm{ml}$ & & $2.34 \pm 0.01^{\mathrm{d}}$ & $1.59 \pm 0.01^{\mathrm{d}}$ & $5.12 \pm 0.00^{\mathrm{a}}$ & $6.00 \pm 0.00^{\mathrm{b}}$ & $60.81 \pm 0.02^{\mathrm{a}}$ \\
Control & & $26.16 \pm 0.01^{\mathrm{a}}$ & $2.53 \pm 0.01^{\mathrm{a}}$ & $1.76 \pm 0.01^{\mathrm{a}}$ & $3.85 \pm 0.00^{\mathrm{c}}$ & $6.85 \pm 0.00^{\mathrm{a}}$ & $58.85 \pm 0.03^{\mathrm{d}}$ \\
$5 \mathrm{ml}$ & \multirow{2}{*}{ 60 Days } & $24.10 \pm 0.00^{\mathrm{a}}$ & $2.41 \pm 0.00^{\mathrm{a}}$ & $1.65 \pm 0.00^{\mathrm{a}}$ & $5.85 \pm 0.00^{\mathrm{b}}$ & $5.90 \pm 0.00^{\mathrm{a}}$ & $60.09 \pm 0.00^{\mathrm{d}}$ \\
$10 \mathrm{ml}$ & $23.96 \pm 0.01^{\mathrm{b}}$ & $2.38 \pm 0.01^{\mathrm{b}}$ & $1.52 \pm 0.00^{\mathrm{b}}$ & $5.88 \pm 0.00^{\mathrm{b}}$ & $5.90 \pm 0.00^{\mathrm{a}}$ & $61.02 \pm 1.43^{\mathrm{a}}$ \\
$15 \mathrm{ml}$ & & $22.79 \pm 0.01^{\mathrm{c}}$ & $2.30 \pm 0.00^{\mathrm{c}}$ & $1.55 \pm 0.00^{\mathrm{b}}$ & $6.20 \pm 0.00^{\mathrm{a}}$ & $5.90 \pm 0.00^{\mathrm{a}}$ & $60.22 \pm 0.01^{\mathrm{c}}$ \\
Control & & $24.12 \pm 0.01^{\mathrm{a}}$ & $2.25 \pm 0.01^{\mathrm{d}}$ & $1.50 \pm 0.00^{\mathrm{c}}$ & $5.72 \pm 0.00^{\mathrm{c}}$ & $5.95 \pm 0.00^{\mathrm{a}}$ & $60.47 \pm 0.02^{\mathrm{b}}$ \\
\hline
\end{tabular}

Means with the same superscript alphabet along the column for each storage duration are not statistically different at $\mathrm{p}<0.05$.

Key:DOS $=$ Duration of Storage; C.= Crude; MOIST.= Moisture; CARB $=$ Carbohydrate; \%= Percentage.

TABLE II: COMPARISON OF THE EFFECT OF STORAGE DURATION ON PROXIMATE COMPOSITIONS OF COWPEA APPLIED SNIPER AT DIFFERENT CONCENTRATIONS

\begin{tabular}{cccccccc}
\hline \multirow{2}{*}{$\begin{array}{c}\text { Sniper } \\
\text { conc. }\end{array}$} & $\begin{array}{c}\text { Duration of } \\
\text { storage }\end{array}$ & \multicolumn{5}{c}{ Proximate composition (\%) } \\
\cline { 3 - 7 }$y$ & C. Protein & Fat & C. Fibre & Ash & Moist. & Carb. \\
\hline $5 \mathrm{ml}$ & 30 days & $25.95 \pm 0.01^{\mathrm{a}}$ & $2.45 \pm 0.00^{\mathrm{a}}$ & $1.70 \pm 0.01^{\mathrm{a}}$ & $4.00 \pm 0.00^{\mathrm{b}}$ & $6.00 \pm 0.00^{\mathrm{a}}$ & $59.90 \pm 0.01^{\mathrm{b}}$ \\
& 60 days & $24.10 \pm 0.01^{\mathrm{a}}$ & $2.41 \pm 0.00^{\mathrm{a}}$ & $1.65 \pm 0.01^{\mathrm{a}}$ & $5.85 \pm 0.00^{\mathrm{a}}$ & $5.90 \pm 0.00^{\mathrm{b}}$ & $60.09 \pm 0.01^{\mathrm{a}}$ \\
& 30 days & $25.13 \pm 0.01^{\mathrm{a}}$ & $2.40 \pm 0.00^{\mathrm{a}}$ & $1.62 \pm 0.01^{\mathrm{a}}$ & $4.00 \pm 0.00^{\mathrm{b}}$ & $6.00 \pm 0.00^{\mathrm{a}}$ & $60.86 \pm 0.01^{\mathrm{a}}$ \\
& 60 days & $23.96 \pm 0.01^{\mathrm{b}}$ & $2.38 \pm 0.00^{\mathrm{a}}$ & $1.52 \pm 0.01^{\mathrm{b}}$ & $5.88 \pm 0.00^{\mathrm{a}}$ & $5.90 \pm 0.00^{\mathrm{b}}$ & $61.02 \pm 0.01^{\mathrm{a}}$ \\
& 30 days & $24.15 \pm 0.01^{\mathrm{a}}$ & $2.34 \pm 0.00^{\mathrm{a}}$ & $1.59 \pm 0.01^{\mathrm{a}}$ & $5.12 \pm 0.00^{\mathrm{b}}$ & $6.00 \pm 0.00^{\mathrm{a}}$ & $60.81 \pm 0.01^{\mathrm{a}}$ \\
& 60 days & $22.79 \pm 0.01^{\mathrm{b}}$ & $2.30 \pm 0.00^{\mathrm{a}}$ & $1.42 \pm 0.01^{\mathrm{b}}$ & $6.20 \pm 0.00^{\mathrm{a}}$ & $5.90 \pm 0.00^{\mathrm{b}}$ & $60.22 \pm 0.01^{\mathrm{b}}$ \\
& 30 days & $26.16 \pm 0.01^{\mathrm{a}}$ & $2.53 \pm 0.00^{\mathrm{a}}$ & $1.76 \pm 0.01^{\mathrm{a}}$ & $3.85 \pm 0.00^{\mathrm{a}}$ & $6.85 \pm 0.00^{\mathrm{a}}$ & $58.85 \pm 0.01^{\mathrm{b}}$ \\
& 60 days & $24.12 \pm 0.01^{\mathrm{b}}$ & $2.25 \pm 0.00^{\mathrm{b}}$ & $1.50 \pm 0.01^{\mathrm{b}}$ & $5.72 \pm 0.00^{\mathrm{b}}$ & $5.95 \pm 0.00^{\mathrm{b}}$ & $60.47 \pm 0.01^{\mathrm{a}}$ \\
\hline
\end{tabular}

Means with the same superscript alphabet along the column for each concentration are not statistically significantly different at $\mathrm{p}<0.05$.

TABLE III: MinERAL NUTRIENT COMPOSITIONS OF COWPEA AT DIFFERENT DURATION OF STORAGE AFTER APPLICATION OF SNIPER CHEMICAL

\begin{tabular}{|c|c|c|c|c|c|c|}
\hline \multirow{2}{*}{ Treatment } & \multirow{2}{*}{ Concentration } & \multirow{2}{*}{ Dos } & \multicolumn{4}{|c|}{ Mineral composition $(\mathrm{mg} / 100 \mathrm{~g})$} \\
\hline & & & $\mathrm{P}$ & $\mathrm{Ca}$ & $\mathrm{Mg}$ & $\mathrm{K}$ \\
\hline \multirow{3}{*}{ Sniper } & $5 \mathrm{ml}$ & \multirow{3}{*}{30 Days } & $185.03 \pm 0.01^{\mathrm{c}}$ & $226.32 \pm 0.02^{\mathrm{c}}$ & $80.76 \pm 0.01^{\mathrm{c}}$ & $595.25 \pm 0.01^{\mathrm{c}}$ \\
\hline & $10 \mathrm{ml}$ & & $193.33 \pm 0.01^{\mathrm{b}}$ & $240.15 \pm 0.00^{\mathrm{b}}$ & $82.64 \pm 0.02^{b}$ & $615.64 \pm 0.01^{\mathrm{b}}$ \\
\hline & $15 \mathrm{ml}$ & & $195.54 \pm 0.02^{\mathrm{a}}$ & $245.76 \pm 0.01^{\mathrm{a}}$ & $85.92 \pm 0.01^{\mathrm{a}}$ & $642.34 \pm 0.01^{\mathrm{a}}$ \\
\hline \multirow{5}{*}{ Sniper } & Control & \multirow{5}{*}{60 Days } & $178.54 \pm 0.02^{\mathrm{d}}$ & $211.26 \pm 0.01^{\mathrm{d}}$ & $75.86 \pm 0.01^{\mathrm{d}}$ & $545.26 \pm 0.01^{\mathrm{d}}$ \\
\hline & $5 \mathrm{ml}$ & & $186.54 \pm 0.01^{\mathrm{c}}$ & $251.07 \pm 0.01^{\mathrm{c}}$ & $86.48 \pm 0.01^{\mathrm{c}}$ & $650.06 \pm 0.01^{\mathrm{c}}$ \\
\hline & $10 \mathrm{ml}$ & & $194.76 \pm 0.01^{\mathrm{b}}$ & $260.04 \pm 0.01^{\mathrm{b}}$ & $88.45 \pm 0.00^{\mathrm{b}}$ & $658.76 \pm 0.01^{\mathrm{b}}$ \\
\hline & $15 \mathrm{ml}$ & & $198.65 \pm 0.01^{\mathrm{a}}$ & $262.73 \pm 0.01^{\mathrm{a}}$ & $90.12 \pm 0.00^{\mathrm{a}}$ & $700.04 \pm 0.01^{\mathrm{a}}$ \\
\hline & Control & & $185.93 \pm 0.01^{\mathrm{d}}$ & $243.32 \pm 0.01^{\mathrm{d}}$ & $84.17 \pm 0.01^{\mathrm{d}}$ & $633.27 \pm 0.02^{\mathrm{d}}$ \\
\hline
\end{tabular}

Means with the same superscript alphabet along the column for each duration of storage are not statistically significantly different at $\mathrm{p}<0.05$.

Key:DOS= Duration of Storage; $\mathrm{P}=$ phosphorus; $\mathrm{Ca}=$ Calcium; $\mathrm{Mg}=$ Magnesium; $\mathrm{K}=$ Potassium. 
C. Comparison of the Effect of Storage Duration on Mineral Compositions of COWPEA applied Sniper at Different Concentrations

Comparison of the effect of storage durations on the minerals composition of the cowpea applied sniper at different quantity showed that at 60 days after storage, all the mineral contents ( $\mathrm{P}, \mathrm{Ca}, \mathrm{Mg}$, and $\mathrm{K}$ ) analyzed were significantly the highest and those of 30 days after storage the lowest. Similar observation was made in the control cowpea sample, except the $\mathrm{K}$ content which was significantly the highest at 30 days after storage and lowest at 60 days (Table IV).

TABLE IV: COMPARISON OF THE EFFECT OF STORAGE DURATION ON MiNERAL COMPOSITIONS OF COWPEA APPLIED SNIPER AT DIFFERENT

\begin{tabular}{cccccc}
\hline \multicolumn{5}{c}{ CONCENTRATIONS } \\
\hline \multirow{2}{*}{$\begin{array}{c}\text { Sniper } \\
\text { conc. }\end{array}$} & $\begin{array}{c}\text { Duration of } \\
\text { storage }\end{array}$ & \multicolumn{4}{c}{ Mineral composition $(\mathrm{mg} / 100 \mathrm{~g})$} \\
\cline { 2 - 6 } $5 \mathrm{ml}$ & 30 days & $185.03 \pm 0.01^{\mathrm{b}}$ & $226.32 \pm 0.02^{\mathrm{b}}$ & $80.76 \pm 0.01^{\mathrm{b}}$ & $595.25 \pm 0.01^{\mathrm{b}}$ \\
& 60 days & $186.54 \pm 0.01^{\mathrm{a}}$ & $251.08 \pm 0.01^{\mathrm{a}}$ & $86.47 \pm 0.01^{\mathrm{a}}$ & $650.06 \pm 0.01^{\mathrm{a}}$ \\
\multirow{3}{*}{$10 \mathrm{ml}$} & 30 days & $193.33 \pm 0.01^{\mathrm{b}}$ & $240.15 \pm 0.00^{\mathrm{b}}$ & $82.64 \pm 0.02^{\mathrm{b}}$ & $615.64 \pm 0.01^{\mathrm{b}}$ \\
& 60 days & $194.76 \pm 0.01^{\mathrm{a}}$ & $260.04 \pm 0.01^{\mathrm{a}}$ & $88.45 \pm 0.00^{\mathrm{a}}$ & $658.76 \pm 0.01^{\mathrm{a}}$ \\
& 30 days & $195.54 \pm 0.02^{\mathrm{b}}$ & $245.76 \pm 0.01^{\mathrm{b}}$ & $85.92 \pm 0.01^{\mathrm{b}}$ & $642.34 \pm 0.01^{\mathrm{b}}$ \\
& 60 days & $198.65 \pm 0.01^{\mathrm{a}}$ & $262.73 \pm 0.01^{\mathrm{a}}$ & $90.12 \pm 0.00^{\mathrm{a}}$ & $700.04 \pm 0.01^{\mathrm{a}}$ \\
& 30 days & $178.54 \pm 0.02^{\mathrm{b}}$ & $211.26 \pm 0.01^{\mathrm{b}}$ & $75.86 \pm 0.01^{\mathrm{b}}$ & $545.26 \pm 0.01^{\mathrm{a}}$ \\
& 60 days & $182.23 \pm 0.01^{\mathrm{a}}$ & $243.32 \pm 0.01^{\mathrm{a}}$ & $84.17 \pm 0.01^{\mathrm{a}}$ & $633.27 \pm 0.02^{\mathrm{b}}$ \\
\hline
\end{tabular}

Means with the same superscript alphabet along the column for each concentration are not statistically significantly different at $\mathrm{p}<0.05$.

\section{DISCUSSION}

Storage of farm produce is an efficient way of ensuring the continued availability of foods throughout the year for human and animal consumption. The foods consumed are the only source of the essential nutrients (carbohydrates, proteins, vitamins, minerals, fat and oils and water) needed by the body for growth and development, and efficient functioning of its systems. However, the qualities of stored foods are mostly influenced by the method and duration of storage [18]. Cowpea is one among the numerous grains being stored by humans so as to ensure its continued availability throughout the seasons; as it is a confirmed and important source of plant protein and other nutrients [19], [20]. Different methods are used in storing this farm produce. These include the use of airtight container and chemicals (both biosynthetic and artificially synthetized) to that could aid in repelling insects capable of destroying the seed endosperm. The chemical 2,3dichlorovinyl dimethyl phosphate, commonly called "sniper" is one of such artificially synthesized chemical used by some farmers in storing this product for some reasonable period of time. This study evaluated the quality of cowpea stored with this chemical at different duration of storage. It was discovered, after 30 and 60 days of storage (as observed in Table I), that the cowpea contained varied percentages of the proximate compositions analyzed, with the carbohydrate content being the highest followed by that of the protein whereas the crude fibre the lowest. Similar findings were reported by several researchers [21], [20]. These contents are indications of cowpea being a good source of protein and carbohydrate. The protein, fat, fibre and moisture contents of the cowpea at 30 days after being treated with different concentrations of sniper indicated decreased in content with increase in treatment. Decrease in these contents (protein, fat, and moisture), especially in cowpea, were associated with increase in microbial activities, which according to findings is responsible for deterioration of protein and fat and eventually lead to increase in moisture content [18]. Therefore, it obvious from these findings that the treatments did not halt the microbial activities that could lead in the deterioration and decrease in contents like protein, fat, and moisture. This is justifiable from the result of the control sample which recorded the highest of the contents while the sample treated with the highest treatment concentration had the lowest. Apparent from the results also, was the fact the carbohydrate and ash contents of the cowpea increase with increase in treatment concentrations. The sample with no treatment (control) had the lowest of both the carbohydrate and ash contents while the sample treated with the highest treatment concentration had the higher of the two contents. The cowpea sample analyzed at 60 days after treatment application was in comparison with that of day 30 of treatment application (as observed in Table II) showed a further decreased in most of the proximate compositions with increased in treatment concentration. This further reduction in these proximate compositions cannot be unconnected to the effect of microbial activities as claimed by [22]; or effect of storage duration or the sniper as attributed to by [18] when they studied the effect of storage duration and media. The cowpea ash content on the contrary, just like at day 30, was observed to increase with further increase in treatment concentration as a result of which the ash content at day 60 was significantly higher than that of day 30 at all treatment concentrations. It's possible that the treatments as well as the storage duration were the contributing factors. The cowpea moisture content at day 60 of storage, declined in content; and was in comparison with that of day 30 significantly lower at all the treatment concentrations. This outcome falls within the moisture content reported by [20] in brown and white cowpea. However, this contradicts the findings of [18], who reported significant increase in moisture content with increase in storage duration from 4 weeks (28 days) to 16 weeks (64 days). The contradiction in the moisture content may be ascribed to the differences in the treatment type used in this study and theirs.

The mineral nutrients of the cowpea analyzed at both 30 and 60 days after treatment application were noticed to increase with increase in the sniper's concentration and storage duration as a result of which all the mineral contents at day 60 were significantly higher than that at day 30 . The $P$, $\mathrm{Ca}, \mathrm{Mg}$ and $\mathrm{K}$ contents at day 30 ranges between 185.03$195.54 \mathrm{mg} / 100 \mathrm{~g}, \quad 226.32-245.76 \mathrm{mg} / 100 \mathrm{~g}, \quad 80.76$ $85.92 \mathrm{mg} / 100 \mathrm{~g}$ and $595.25-642.34 \mathrm{mg} / 100 \mathrm{~g}$, respectively; and at day 60 it ranges between 186.54-198.65 mg/100 g, 
251.07-262.73 mg/100 g, 86.48-90.12 mg/100 g and 650.06$700.04 \mathrm{mg} / 100 \mathrm{~g}$, respectively. The mineral content of the control sample at the two storage durations were significantly lower than those of all the chemical treatment rates. The increase in mineral content justifies the increase in the ash content at both the storage durations and treatment rates. This indicated that high ash content of a sample means more mineral nutrients.

\section{CONCLUSION}

The effects of sniper as a storage chemical of cowpea over a specified period of time have been investigated and the following conclusions are made:

Sniper (2,3-dichlorovinyl dimethyl phosphate) significantly affected the quality of proximate and mineral compositions of cowpea. The effect depends on rate of application and the duration of storage after the sniper application.

The effect is more on the proximate compositions which involved: crude protein, fat, and ash contents of cowpea than on crude fibre, moisture and carbohydrate contents.

Increase in storage duration of cowpea applied sniper at different concentrations would mean significant increase in the mineral nutrients such as $\mathrm{P}, \mathrm{Ca}, \mathrm{Mg}$ and $\mathrm{K}$.

\section{RECOMMENDATION}

The use of 2,3-dichlorovinyl dimethyl phosphate (sniper) in storing/preserving cowpea, with the intention of repelling insects should be discouraged as it affects the quality of most of the proximate compositions. Storage duration of cowpea should also be minimized as the longer is the period of storage, the lesser the quality of proximate compositions.

\section{CONFLICT OF INTEREST}

The authors declared no conflict of interest.

\section{ACKNOWLEDGMENT}

The authors wished to thank all the laboratory staff who assisted in running the analysis of this study.

\section{REFERENCES}

[1] Boukar O., Belko N., Chamarthi S., Togola A., Batiemo J., Owusu E., Haruna M., Diallo S., Umar M. L. and Olufajo O. Cowpea (Vignaunguiculata): Genetics, genomics and breeding. Plant Breeding, 2019, 138:415-424.

[2] Langyintuo A. S., Lowenberg-De_Boer J., Faye M., Lambert D., Ibro G. and Moussa B. Cowpea supply and demand in West and Central Africa. Field Crops research, 2003, 82:215-231.

[3] Langyintuo A. S., LOwenberg-De-Boer J. and Arndt C. Potential impact of the proposed West African monetary zone on cowpea trade in West and Central Africa. Agricultural Economics, 2005, 33:41-421.

[4] Reis C. and Frederico A. Genetic diversity in cowpea (Vignaunguiculata) using isozyme electrophoresis. ActaHortic, 2001, 546:497-501.

[5] Anele U. Y., Arigbede O. M., Sudekum K. H., Ike K. A., Oni A. O., Olanite J. A., Amole G. A., Dele P. A. and Jolaosho A. O. Effects of processed cowpea (Vignaunguiculata L. Walp) haulms as a feed supplement on voluntary intake, utilization and blood profile of West African dwarf sheep fed a basal diet of Pennisetumpurpureum in the dry season. Animal Feed Science and Technology, 2010, 159(1-2):1017.

[6] Abadassi J. Cowpea (Vignaunguiculata (L.) Walp). Agronomic traits needed in tropical zone. International Journal of Pure and Applied Bioscience, 2015, 3:158-165.

[7] Jayathilake C., Visvanathan R., Deen A., Bangamuwage R. Jayawardana B. C., Nammi S. and Liyanage R. Cowpea: an overview on its nutritional facts and health benefits. Journal of Science, Food and Agriculture, 2018, 98(13):4793-4806.

[8] Gonclaves A., Goufo P., Trindade H., Rosa E. A., Ferreira L. and Dominguez-peris R. Cowpea (Vignaunguiculata L. Walp), a renowed multi-purpose crop for a more sustainable agriculture food system: nutritional advantages and constraints. Journal of Science, food and agriculture, 2016, 96:2941-2951.

[9] Uduak I. A. Comparison of the proximate and mineral compositions of two cowpea varieties obtained from Mile 12 market, Lagos. Communication in physical sciences, 2018, 3(1):43-48.

[10] Asante I. K., Adu-Dapaah H. and Acheampong,A. O. Determination of some mineral components of cowpea (Vignaunguiculata (L.) Walp) using instrumental neutron activation analysis. West African Journal of Applied Ecology, 2007, 11(1):11-17.

[11] Baributsa D., Lowenberg-De-Boer J., Murdock L. and Moussa B. Profitable chemical free cowpea storage technology for small holder farmers in Africa: opportunity and challenges. $10^{\text {th }}$ International Working Conference on stored product protection, International Programs in Agriculture, 615 W. State street, Purdue Univeristy, West Lafayette, 2010, 1046-1052pp.

[12] Boys K. Adoption and economic impact implications of storage technology and improved cowpea varieties in the north central peanut basin of Senegal. M.Sc thesis, Department of Agricultural economics, Purdue University, West Lafayette, IN, USA, 2005.

[13] Moussa B. Economic impact assessment of cowpea storage technology. M.Sc thesis, Department of Agricultural Economics, Purdue University, West Lafayette, IN, USA, 2006.

[14] Carlos G. Cowpea: Post Harvest Operation, Food and Agriculture organization of United Nations, Rome, 2000.

[15] Baoua I., Laouali A., Venu M. M. and Larry L. M. Comparative evaluation of six storage methods for postharvest preservation of cowpea grain. Journal of Stored Products Research, 2012, 49:171-175.

[16] Ogunkanmi L. A., Ogundipe O. T., Amusa O. D., Bolarinwa B. and Akindele O. O. A. Comparative evaluation of cold and container storage preservation efficiencies on cowpea grains against Callosbruchusmaculatus, Fab. Agricultura, 2018, 107:20-28.

[17] AOAC. Official Methods of analysis of AOAC international, 17 $7^{\text {th }}$ Edition, Arlington, AOAC international, Gaitherburg, MD, USA, 2000.

[18] Aremu D. O., Babajide N. A., Ogunlade C. A., Oyeniran T. and Kadiri A. O. Effects of storage media and duration on nutritional qualities of cowpea (VignaunguiculataL.Walp). Journal of Agriculture and Veterinary Science, 2015, 8(2):60-65.

[19] Alayande L. B., Mustapha K. B., Dabak J. D. and Ubom G. A Comparison of nutritional values of brown and white beans in Jos North local government markets. African Journal of Biotechnology, 2012, 11:43.

[20] Uduak I. A. Comparison of the proximate and mineral compositions of two cowpea varieties obtained from Mile 12 market, Lagos. Communication in physical sciences, 2018, 3(1):43-48.

[21] Maalekuu B. K. and Koley E. N. A survey on methods used in the storage of some varieties of cowpea (Vignaunguiculata L.) and their effect on quality (A case study of EjuraSekyedumase District). Agriculture and Biology Journal of North America, 2014, 5(2):40-50.

[22] Hellevong K. L. Dryenation of grain seeds. Journal of Agricultural Research, 2000, 54:15. 